\title{
Spirematospermum wetzleri (Heer) Chandler (Zingiberaceae) from the Miocene of Weichang, Hebei Province, North China and the phytogeographic history of the genus
}

Ya Li $i^{1,2}$, Tie-Mei Yi ${ }^{1,3}$, Yue-Zhuo Li ${ }^{4}$ and Cheng-Sen $\mathrm{Li}^{i^{*}}$

\begin{abstract}
Spirematospermum is a well-known extinct zingiberalean taxon, characterized by trilocular capsules containing many distinctive, spirally striate and arillate seeds. It is frequently found and studied in European Neogene carpological floras, but is scarcely represented in East Asia floras. In this work we recognize a new fossil record of Spirematospermum wetzleri (Heer) Chandler based on the capsules and seeds from the Miocene of Weichang, Hebei Province, North China. These fossils represent the first record of the species in the Miocene of China. Fossil data indicate that Spirematospermum probably originated in the Late Cretaceous of North America or Central Europe. The genus still existed in the Paleocene of North America, but became extinct after that time. However, the genus successively survived in Europe from the Eocene to Pliocene, and flourished luxuriantly during the Oligocene to Miocene. As there was Turgai Strait between Europe and Asia during the Eocene, the genus did not spread to Central Asia and West Siberia until the strait closed in the late Eocene/early Oligocene, and further expanded eastwardly to eastern Siberia, Russia, northern China and central Japan during the Miocene, but became extinct in Asia after the Miocene. The genus contracted its distribution to Europe in the Pliocene, and afterwards it became extinct in the world.
\end{abstract}

Keywords: Spirematospermum, Zingiberaceae, Musaceae, Phytogeographic history, Neogene, Miocene, Weichang, North China

\section{Introduction}

Spirematospermum Chandler (Zingiberales) is an extinct genus, established for trilocular capsules containing many distinctive seeds with spirally striate testa and aril (Chandler 1925; Friedrich and Koch 1970; Fischer et al. 2009). Spirematospermum has long been a subject of controversy regarding its systematic affinity, since Heer (1859) first described its capsules and seeds from the Miocene of Günzburg, Germany, but he identified them as Gardenia wetzleri Heer (Rubiaceae). Then, Ludwig (1860) described its capsules from the Miocene of Salzhausen and other localities, Germany as Passiflora braunii Heer \& Ludwig (Passifloraceae). Menzel (1913)

\footnotetext{
*Correspondence: lics@ibcas.ac.cn

'State Key Laboratory of Systematic and Evolutionary Botany, Institute of Botany, Chinese Academy of Sciences, Beijing 100093, China

Full list of author information is available at the end of the article
}

suggested a possible relationship with monocotyledonous plants. Chandler (1925) studied its capsules and seeds from the late Eocene of Hordle, Hants, UK, and intensively examined many extant plants, but only in the family Zingiberaceae did they find similar peculiar seed structure, so he established a new genus, Spirematospermum, to accommodate these fossils and named them as S. wetzleri (Heer) Chandler. Friedrich and Koch (1970) further pointed out that $S$. wetzleri is quite similar to the living species Alpinia oxymitra K.Schum. (syn. Cenolophon oxymitrum (K.Schum.) Holttum) (Zingiberaceae) based on comparative study between extant Zingiberaceous materials and 70 capsules and hundreds of seeds fossils from the Miocene of Jutland, Denmark. This opinion was strengthened by their following studies (Koch and Friedrich 1971; Friedrich and Koch 1972). 
However, Manchester and Kress (1993) noticed that the unribbed fruits that taper into the basal stalk, multiple seeds per locule and the presence of a chalazal chamber in the seed suggest a close affinity to Musaceae, but Spirematospermum possesses a spirally striate testa that is found today in Zingiberaceae, not in Musaceae, thus displays combined characters of both Musaceae and Zingiberaceae. Rodríguez-de la Rosa and Cevallos-Ferriz (1994) interpreted Spirematospermum as a member of the Musaceae based on the presence of a chalazal chamber and hilar cavity in seeds. Fischer et al. (2009) made a comprehensive study of S. wetzleri based on an extraordinary mass occurrence of capsules and seeds, petioles, a putative pollen grain, associated rhizomes and Zingiberales-type leaves, and phytoliths of these organs from the middle Miocene of Ponholz, Germany. They placed Spirematospermum as sister to Musa L. + Ensete Bruce ex Horan. clade and proposed a new subfamily Parietimusoideae in the Musaceae to accommodate Spirematospermum, taking into account its capsule with parietal placentation and probable rhizomatous growth.

Smith et al. (2012, 2014) studied the seeds of over 50 extant species from all eight families of Zingiberales, plus the fossil Spirematospermum by synchrotron X-ray tomographic microscopy (SRXTM), and found that a chalazal chamber is not diagnostic of Musaceae, but also was found in Costaceae and tribe Alpiniae (Zingiberaceae), thus suggesting an affinity of Spirematospermum with subfamily Alpinioideae within Zingiberaceae again. The result was strengthened by the phytolith study of Zingiberales that both Zingiberaceae and Spirematospermum produce silica sand but Musaceae produce troughs (Chen and Smith 2013).
Spirematospermum has an exceptionally wide distribution in space and time, ranging from the Late Cretaceous of North America and Europe to the Paleogene and Neogene of Eurasia, and exists as a common element in many European Neogene carpological floras (Fischer et al. 2009; Smith et al. 2014), but it is less represented and studied in East Asia. Here we reported the capsules and seeds of Spirematospermum from the early Miocene of Weichang, Hebei Province, North China, which was preliminary identified to the genus by Yi et al. (2008). And in this article, we further identified them as $S$. wetzleri by comparison with all fossil species of the genus. Based on the fossil record of Spirematospermum, the biogeographic history and possible migration routes of the genus are discussed.

\section{Materials and methods}

The specimens described here were collected from an outcrop at Gaoshanjian (42 $07^{\prime} 33^{\prime \prime} \mathrm{N}, 117^{\circ} 50^{\prime} 28^{\prime \prime} \mathrm{E} ; 1406 \pm$ $16 \mathrm{~m})$, near Guangfayong Town, Weichang County, Chengde City, Hebei Province, North China (Fig. 1). The fossil-bearing beds are lacustrine deposits, which together with its underlying basalts belong to the Hannuoba Formation according to the 1: 200000 geological map of Qipanshan section (K-50-16) (No. 2 Regional Geological Survey Team, Hebei Bureau of Geology and Mineral Resources 1979). The beds were divided into 9 layers (Fig. 2) according to its lithological changes that include mudstone, muddy siltstone, lignite, conglomerate, and shale. Spirematospermum specimens were collected from the 3rd layer (Layer 3; muddy siltstone), the 8th layer (Layer 8; mud stone) and the 9th layer (Layer 9; shale) (Fig. 2). The age of Hannuoba Formation has been interpreted as

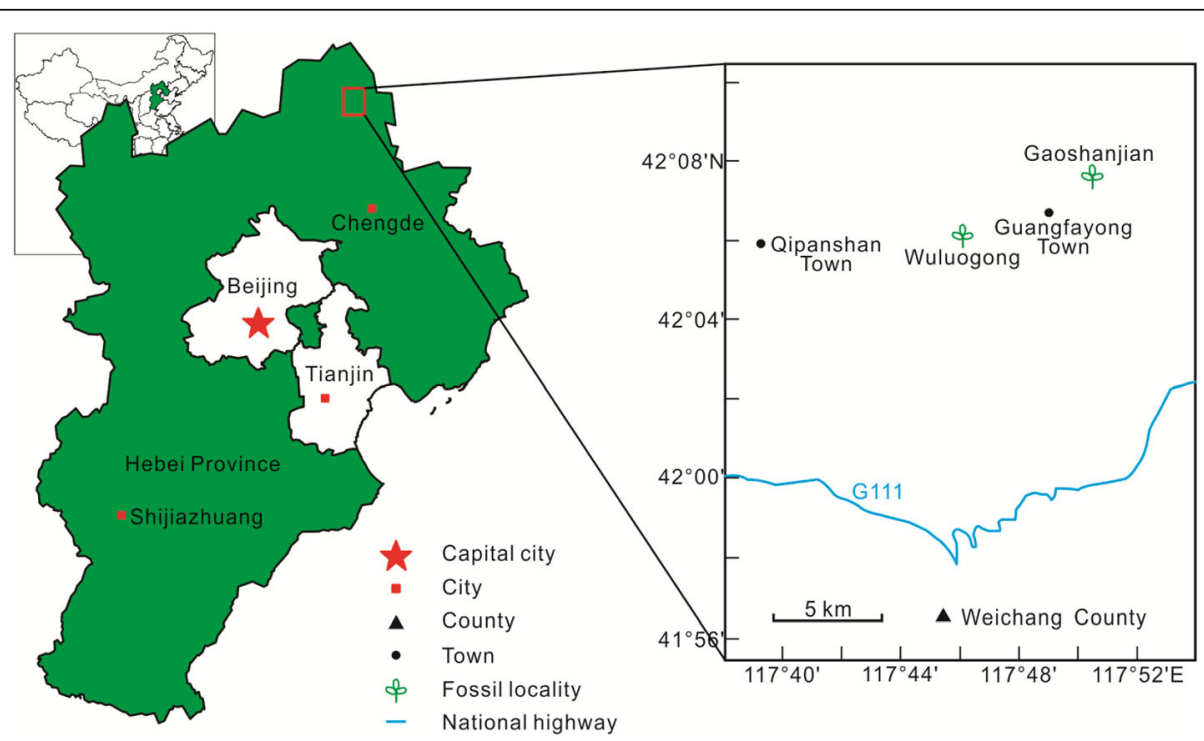

Fig. 1 Map showing fossil locality of Spirematospermum wetzleri at Gaoshanjian (marked as), near Guangfayong Town, Weichang County, Chengde City, Hebei Province, North China. The (insert) map of China was generated by the Maplnfo data in Microsoft Office 2000 


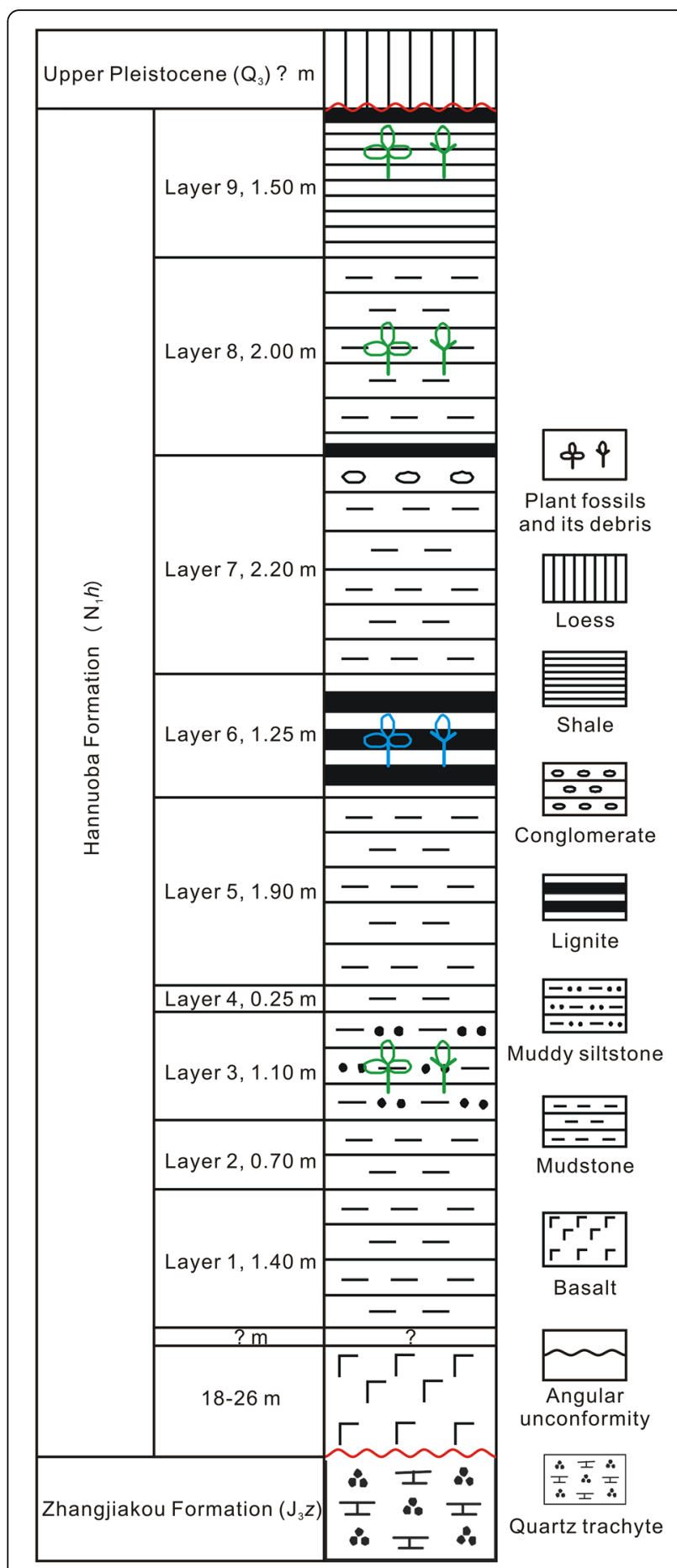

Fig. 2 Stratigraphic and lithologic column of the Gaoshanjian section (modified from $\mathrm{Li}$ et al. 2009), indicating where Spirematospermum wetzleri was found (Green leaves) and the overlying and underlying strata of Hannuoba Formation (No. 2 Regional Geological Survey Team, Hebei Bureau of Geology and Mineral Resources 1979) early Miocene on the basis of fossil mammals Monosaulax changpeiensis $\mathrm{Li}$ and Lagomorpha gen. et sp. indet. From Wafangyingzi, Zhangbei County (Li 1962), plant fossils and sporopollen assemblages as well as the $\mathrm{K}$-Ar radiometric dating of the basalt (22.1 Ma) from Wuluogong, near Guangfayong Town (No. 2 Regional Geological Survey Team, Hebei Bureau of Geology and Mineral Resources 1979).

The plant materials were collected directly from the lignite or separated from the muddy siltstone by washing in water on a 500 um sieve. The materials were successively treated with $10 \% \mathrm{HCl}$ and $48 \% \mathrm{HF}$, and then rinsed with water and air dried. The Spirematospermum specimens with 30 capsules and 50 seeds were all deposited at the National Museum of Plant History of China, the Chinese National Herbarium, Institute of Botany, Chinese Academy of Sciences, and were allocated the inventory numbers PEPB70701-70780. The prefix PE is an international code for the Chinese National Herbarium, while the PB stands for palaeobotanical collections in the National Museum of Plant History of China.

The palaeolatitudes and palaeolongitudes of the fossil localities were converted from the present day coordinates using PointTracker v4c software (Scotese 2001). Sites were plotted on six palaeomaps (Scotese 1997; Smith et al. 2004; LePage et al. 2005) of Lambert Equal-Area Azimuthal (North Pole) projections using ArcView GIS 3.2 software, covering the following time intervals: Late Cretaceous $(\sim 80 \mathrm{Ma})$, Paleocene $(\sim 60 \mathrm{Ma})$, Eocene $(\sim$ $50 \mathrm{Ma})$, Oligocene $(\sim 30 \mathrm{Ma})$, Miocene $(\sim 20 \mathrm{Ma})$ and Pliocene ( $5 \mathrm{Ma})$.

\section{Results}

Order: Zingiberales

Family: Zingiberaceae

Genus: Spirematospermum Chandler 1925

Species: Spirematospermum wetzleri (Heer 1859) Chandler 1925.

Description: Fruits are three-dimensionally preserved and compressed, and they are elongate capsules with the fragile apex being eroded away, 2.3-6.2 cm long and 0.8-2.1 cm wide (Fig. 3a, b). They are flattened (Fig. 3a) or polyhedral (Fig. $3 \mathrm{~b}$ ), and tapering into a curved stalk at the base. The surfaces of the capsules are longitudinally ribbed or not ribbed, and ornamented with several distinct longitudinal striations. The capsules are irregularly dehiscent from the apex, containing many seeds inside the locules. Seeds are either isolatedly preserved or in-situ enclosed in capsular fruits, facially compressed, 7.5-12.0 $\mathrm{mm}$ long and $3.0-5.0 \mathrm{~mm}$ wide, irregularly ellipsoidal in outline with an acute or obtuse apex and a truncate, slightly depressed base (Fig. 3c-g). Seeds usually have distinctive, spirally striate testa and a longitudinal furrow in the middle of the seed surface. 

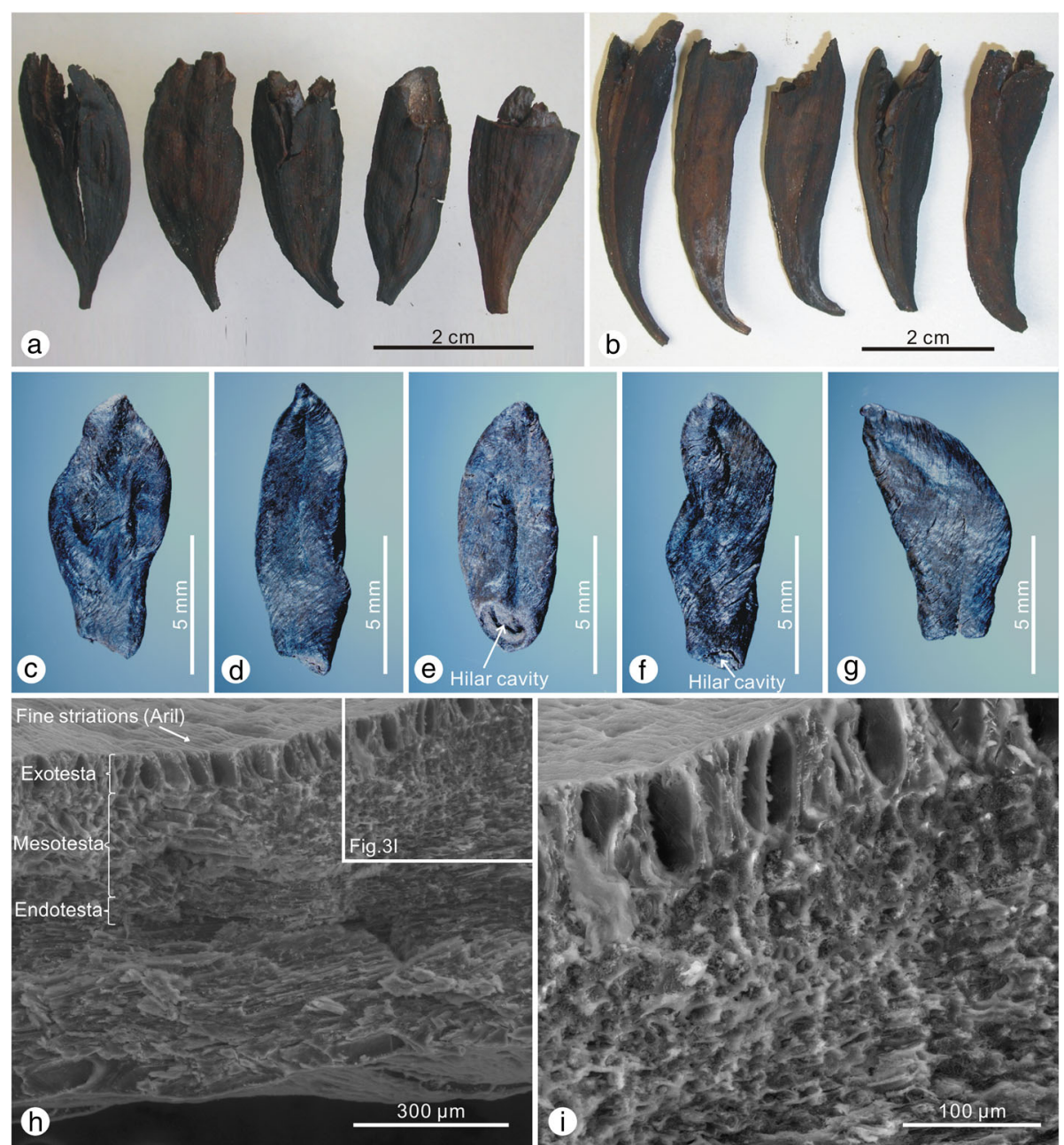

Fig. 3 Capsules and seeds of Spirematospermum wetzleri from the early Miocene of Weichang, Hebei Province, North China. a Five flattened capsules with the apex eroded away, specimen nos. PEPB70701-70705; b Five polyhedral capsules, tapering into a curved stalk at the base, specimen nos. PEPB70706-70710; $\mathbf{c}-\mathbf{g}$ The distinctive, spirally striate and arillate seeds, specimen nos. PEPB70731-70735; $\mathbf{h}$ SEM image of the transverse section of the seed; $\mathbf{i}$ Magnification of the white rectangular part in $\mathbf{h}$

The seed hilum is funnel-shaped with a small central aperture delimiting as hilar cavity (Fig. 3e, f). The seed coat is $0.3-0.4 \mathrm{~mm}$ thick, composed of three distinct layers in transverse section, viz., the exotesta consisting of a palisade layer of uniseriate, sclerified, thick-walled rectangular cells; the mesotesta being formed of isodiametric or elongate cells; and the endotesta comprising a layer of narrow, tangentially elongate sclereids (Fig. 3h, i). The tegmen is not observed in the section. The aril is present, which is indicated by the fine striations running across the outer surface of palisade sclereids (Fig. 3h).

\section{Discussion}

4.1 Comparisons with fossil species of Spirematospermum The Weichang specimens possess the following characters, viz., the elongate capsules tapering at the base into a curved stalk, and the fruits containing many distinctively spirally striate and arillate seeds, which are all indicative of the genus Spirematospermum (Fig. 4). This genus includes two Cretaceous species established only by seeds, viz., $S$. chandlerae Friis from the Santonian or Campanian of North Carolina, USA (Friis 1988), and S. friederichii Knobloch \& Mai from the Maastrichtian of Germany (Knobloch and Mai 1986). The Weichang specimens cannot be assigned to these species, mainly due to their smaller sized seeds (3.6-5.3 $\mathrm{mm} \times 1.0-1.7 \mathrm{~mm}$ for $S$. chandlerae, and 2.0-3.5 $\mathrm{mm} \times 1.0-1.5 \mathrm{~mm}$ for $S$. friederichii). This genus includes only one Cenozoic species, viz., S. wetzleri (Fig. 4), reported from the Paleogene and Neogene of Eurasia (Koch and Friedrich 1971; Fischer et al. 2009). The Weichang specimens can be assigned to this species based on their similar gross morphology and inner structure of capsules and seeds. Reexamining the seeds of Spirematospermum from multiple localities by synchrotron X-ray 


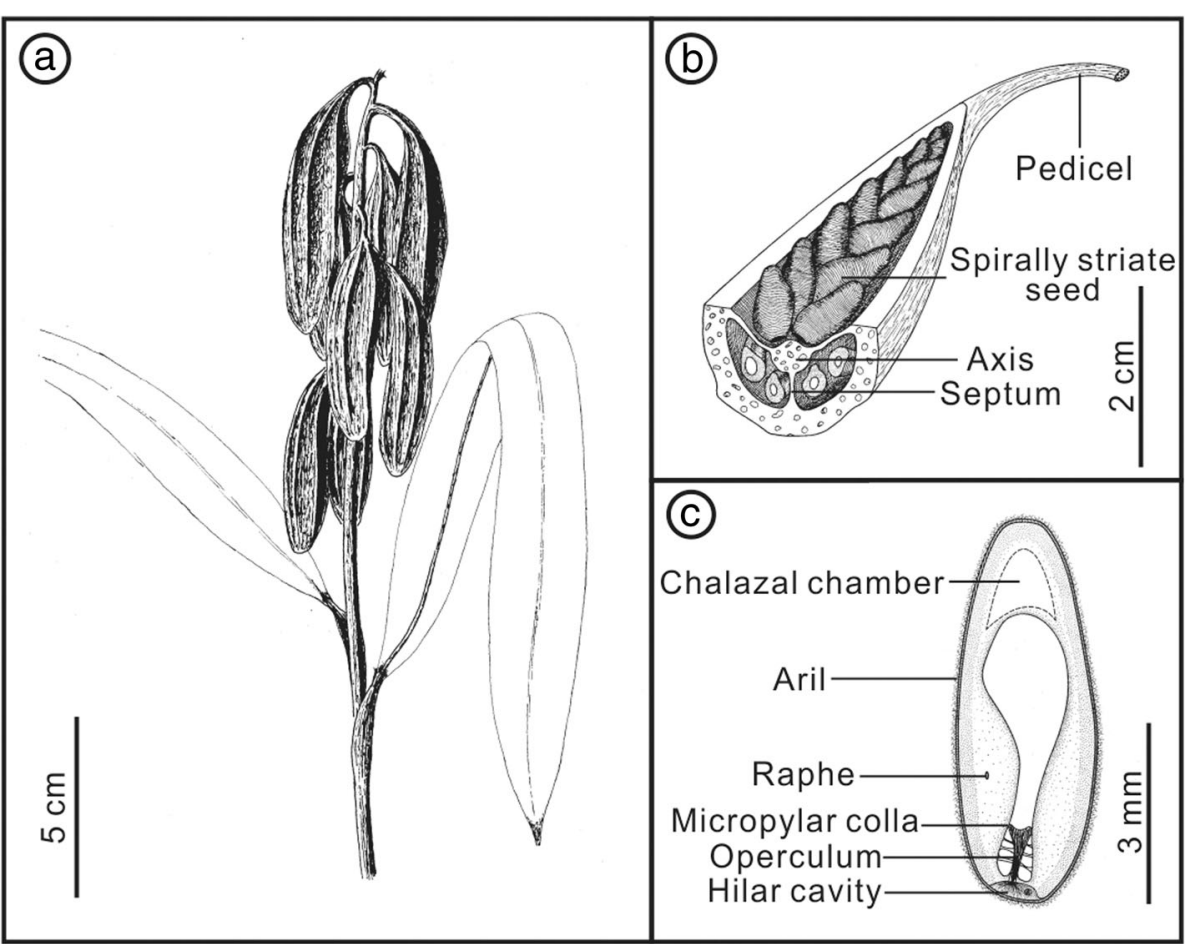

Fig. 4 Sketch drawings illustrating the morphology and anatomy of Spirematospermum wetzleri (Koch and Friedrich 1971). a The plant reconstruction; $\mathbf{b}$ Anatomical structures of a capsule; c Anatomical structures of a seed

tomographic microscopy (SRXTM), Smith et al. (2014) suggested that Spirematospermum sp. from the Cretaceous of Germany should be recognized as a fourth species, and one specimen examined from the Eocene of UK (Collinson 1983) may represent a fifth species. This suggests that Spirematospermum probably has greater species diversity during the geological history than we have recognized.

\subsection{The phytogeographic history of Spirematospermum} The earliest occurrence of Spirematospermum is from the Santonian or Campanian of North Carolina, USA (Friis 1988), followed by the occurrences from the late Campanian to early Maastrichtian of Kössen, Austria (Goth 1986), and the Maastrichtian of Saxony-Anhalt, Germany (Knobloch and Mai 1986) (Fig. 5a). This North America-Europe distribution could be caused by the migrations via the North Atlantic Land Bridge in either direction during the Cretaceous (Fischer et al. 2009) (Fig. 6).

During the Paleocene, Spirematospermum is only reported from the late Paleocene of Beicegel Creek locality, McKenzie County, North Dakota, USA (Benedict et al. 2007; Fig. 5b). There are no younger occurrences of Spirematospermum from North America (Fig. 5c-f). Spirematospermum is known from the Eocene of UK and Germany (Chandler 1925; Collinson 1983; Mai and
Walther 1985; Fig. 5c), and flourished luxuriantly during the Oligocene and Miocene in Europe (Koch and Friedrich 1971; Friis 1988; Fischer et al. 2009; Fig. 5d, e). Spirematospermum probably expanded its distribution eastward into Asia during the Oligocene after the closure of the Turgai Straits in the late Eocene/early Oligocene (Tiffney 1985; Scotese 1997; Sanmartín et al. 2001; Smith et al. 2004), and was further spread eastward into eastern Siberia, Russia, northern China and central Japan during the early Miocene (Nikitin 2007; Yi et al. 2008; Tsukagoshi and Matsuhashi 2012; Figs. 5d, e and 6). Spirematospermum disappeared from Asia and became less abundant in Europe during the Pliocene (Fig. 5f), and finally became extinct after Pliocene. This extinction can be related to climate deterioration during the Pliocene, as today the relatives of Spirematospermum are exclusively tropical and subtropical plants. Its southward migration to cope with the Pliocene/Pleistocene cooling was hampered by the East-West orientation of the Alps, the Mediterranean Sea and the Himalaya (Fischer et al. 2009).

As Spirematospermum wetzleri from Weichang represents the first record of the genus from China, the other two East Asian occurrences of the genus should be mentioned. Of special interest is the occurrence from the early Miocene of Omoloi River basin, Russia (Nikitin 2007), which represents the northernmost occurrence 


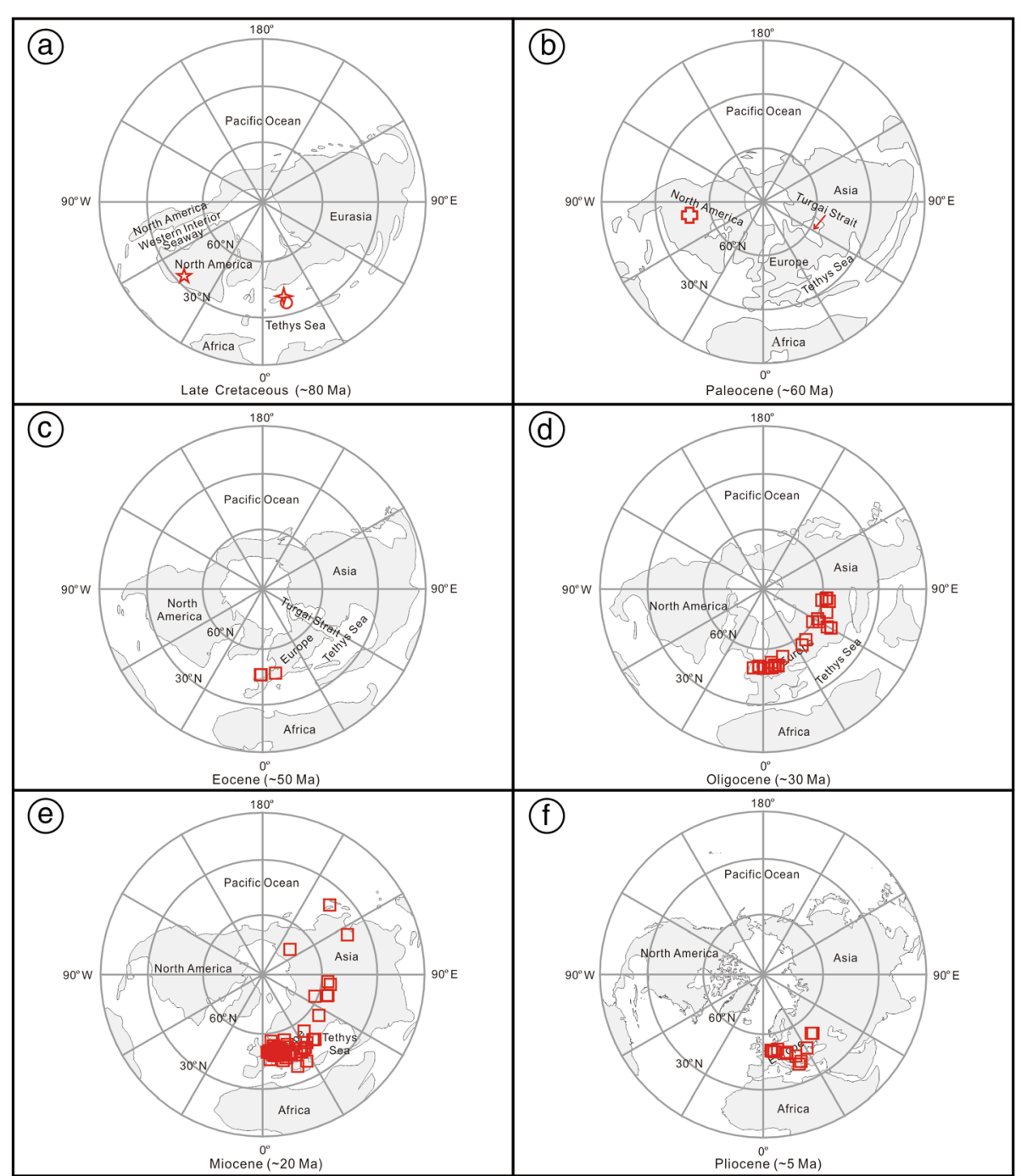

Fig. 5 Palaeogeographic maps showing the distribution of Spirematospermum from the Late Cretaceous to the Pliocene (a-f), based on the Cretaceous occurrences (Goth 1986; Knobloch and Mai 1986; Friis 1988) and the compilation of the Cenozoic occurrences (Fischer et al. 2009). $\downarrow$.

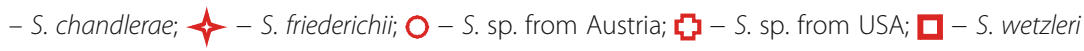

(ca. $71.3^{\circ} \mathrm{N}$ of the palaeolatitude) of the genus for its phytogeographic history. The other occurrence is from the Lower Miocene Nakamura Formation in Kani City, central Japan, representing the first and sole record of the genus in Japan (Tsukagoshi and Matsuhashi 2012).

\subsection{The accompanying flora with Spirematospermum at Gaoshanjian}

The Miocene Gaoshanjian flora is well represented by the fossils of mosses, ferns, conifers and angiosperms ( $\mathrm{Li}$ et al. 2009; Liang et al. 2010, 2013; Guo et al. 2013). Mosses consist of three species: Leptodictyum riparium (Hedw.) Warnst., Drepanocladus subtrichophyllus Caiqing Guo \& al, Amblystegium varium (Hedw.) Lindb., all belonging to the family Amblystegiaceae and suggesting a wet habitat (Guo et al. 2013). Three species of angiosperms, viz., Comptonia naumannii (Nathorst) Huzioka, C. tymensis Dorofeev, Weigela weichangensis Ya $\mathrm{Li} \&$ C.S.Li were discovered from this locality (Liang et al. 2010, 2013). The palynological data of the Gaoshanjian section suggest that the palaeovegetation was a mixed forest of conifers (e.g., Pinus, Picea, Tsuga) and broad-leaved trees (e.g., Betula, Alnus), with some subtropical elements (e.g., Carya), and the palaeoclimate was warm temperate to subtropical (Li et al. 2009).

The putative leaves of Spirematospermum (e.g., Zingiberoideophyllum, Musophyllum) have not been found at this locality. But some aquatic plants such as Nuphar sp. and Potamogeton sp. as well as the wetland plant Epipremnites sp. (under study) were found together with 


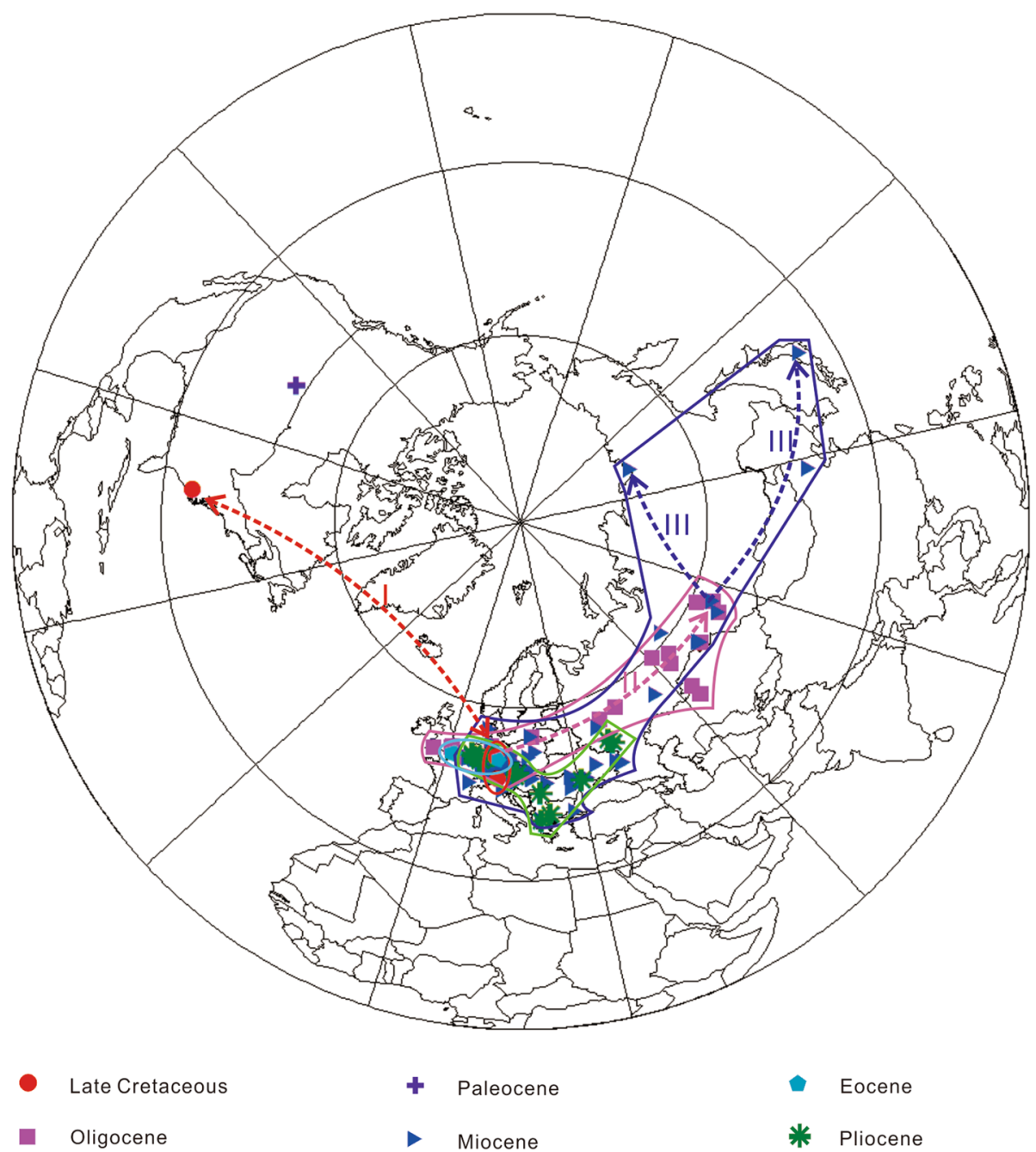

Fig. 6 Distribution and probable spreading map of Spirematospermum during the geological times. I - The red dashed line and arrows indicating the spreading of Spirematospermum via the North Atlantic Land Bridge in either direction during the Late Cretaceous; II - The purple dashed line and arrow indicating eastward expansion of Spirematospermum into Asia during the Oligocene; III - The blue dashed line and arrows indicating further eastward expansion of Spirematospermum into East Asia during the Miocene

Spirematospermum wetzleri, which supports that $S$. wetzleri was an important wetland plant with waterside or swamp habitat (Friis 1988; Fischer et al. 2009).

\section{Conclusions}

We reported an important fossil record of Spirematospermum from the early Miocene of North China. We made a detailed description of the well preserved fruits and seeds, which were assigned to $S$. wetzleri by comparing with related fossil species of the genus. Based on the occurrences of Spirematospermum fossils, we show the biogeographical distribution of the genus for the first time on a series of palaeogeographic maps of the Northern Hemisphere, and illustrate the probable spreading routes and directions. The accompanying flora from the Miocene of North China suggests that $S$. wetzleri lives in a waterside or swamp habitat of a warm temperate to subtropical climate.

\section{Acknowledgements}

We are grateful to the editor and two reviewers for their valuable comments and suggestions for improving the manuscript. This work was supported by the Natural Science Foundation of China (Grants No. 41502017 and No. 41072022), and the Strategic Priority Research Program of the Chinese Academy of Sciences (Grant No. XDPB05).

\section{Authors' contributions}

CSL designed the study. YL, TMY and CSL collected the materials. YL and TMY carried out the experiment and wrote the manuscript. YZL and CSL helped modify the manuscript. All authors read and approved the final manuscript.

Competing interests

The authors declare that they have no competing interests. 


\section{Publisher's Note}

Springer Nature remains neutral with regard to jurisdictional claims in published maps and institutional affiliations.

\begin{abstract}
Author details
${ }^{1}$ State Key Laboratory of Systematic and Evolutionary Botany, Institute of Botany, Chinese Academy of Sciences, Beijing 100093, China. ${ }^{2}$ CAS Key Laboratory of Economic Stratigraphy and Palaeogeography, Nanjing Institute of Geology and Palaeontology, Chinese Academy of Sciences, Nanjing 210008, Jiangsu Province, China. ${ }^{3}$ Beijing Institute of Science and Technology Information, Beijing Academy of Science and Technology, Beijing 100044, China. ${ }^{4}$ Qian-Dao-Hu Museum of Natural History, Hangzhou 311700, Zhejiang Province, China.
\end{abstract}

Received: 8 January 2018 Accepted: 26 March 2018

Published online: 14 September 2018

\section{References}

Benedict, J.C., W. Taylor, K.B. Pigg, and M.L. DeVore. 2007. Late Paleocene seeds from Beicegel Creek (McKenzie County, North Dakota, USA) with affinities to the genus Spirematospermum Chandler (Zingiberales). Chicago: Botany \& Plant Biology 2007 Joint Congress, July 7-11, 2007 Posters for Sections. Poster Number: P54003. Session: P. Abstract ID: 2146. Online

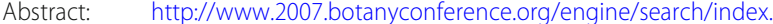
php?func $=$ detail\&aid $=2146$.

Chandler, M.E.J. 1925. The upper Eocene Flora of Hordle, Hants, part I, 32. London: Monograph of the Palaeontographical Society.

Chen, S.T., and S.Y. Smith. 2013. Phytolith variability in Zingiberales: A tool for the reconstruction of past tropical vegetation. Palaeogeography, Palaeodimatology, Palaeoecology 370: 1-12.

Collinson, M.E. 1983. Palaeofloristic assemblages and palaeoecology of the lower Oligocene Bembridge marls, Hamstead ledge, Isle of Wight. Botanical Journal of the Linnean Society 86: 177-225.

Fischer, T.C., R. Butzmann, B. Meller, T. Rattei, M. Newman, and D. Hölscher. 2009. The morphology, systematic position and inferred biology of Spirematospermum An extinct genus of Zingiberales. Review of Palaeobotany and Palynology 157: $391-426$.

Friedrich, W.L., and B.E. Koch. 1970. Comparison of fruits and seeds of Spirematospermum wetzleri (Zingiberaceae) with those of living Cenolophon. Bulletin of the Geological Society of Denmark 20: 192-195.

Friedrich, W.L., and B.E. Koch. 1972. Der Arillus der tertiären Zingiberaceae: Spirematospermum wetzleri. Lethaia 5: 47-59.

Friis, E.M. 1988. Spirematospermum chandlerae sp. nov., an extinct species of Zingiberaceae from the north American cretaceous. Tertiary Research 9: 7-12.

Goth, K. 1986. Erster Nachweis von Spirematospermum-Samen aus der Oberkreide von Kössen in Tirol. Courier Forschungsinstitut Senckenberg 86: 171-175.

Guo, C., J. Yao, P. Wu, and C. Li. 2013. Early Miocene mosses from Weichang, North China, and their environmental significance. Acta Geologica Sinica (English Edition) 87: 1508-1519.

Heer, O. 1859. Flora tertiaria Helvetiae: Die tertiäre flora der Schweiz (Vol. 3), 377. Winterthur: J. Wurster \& Compagnie.

Knobloch, E., and D.H. Mai. 1986. Monographie der Früchte und Samen in der Kreide von Mitteleuropa. Rozpravy Ústréedního ústavu geologického 47: 1-219.

Koch, B.E., and W.L. Friedrich. 1971. Früchte und samen von Spirematospermum aus der Miozänen Fasterholt-Flora in Dänemark. Palaeontographica Abteilung B - Paläophytologie 136: 1-46.

LePage, B.A., H. Yang, and M. Matsumoto. 2005. The evolution and biogeographic history of Metasequoia. In The Geobiology and ecology of Metasequoia, ed. B.A. LePage, C.J. Williams, and H. Yang, 3-114. Dordrecht: Springer.

Li, C.-K. 1962. A tertiary beaver from Changpei, Hopei Province. Vertebrata PalAsiatica 6: 72-79 (in Chinese with English abstract).

Li, J.-F., D.K. Ferguson, Y. Jian, G.P. Feng, A.G. Ablaev, Y.F. Wang, and C.-S. Li. 2009. Early Miocene vegetation and climate in Weichang District, North China. Palaeogeography, Palaeoclimatology, Palaeoecology 280: 47-63.

Liang, X.-Q., Y. Li, Z. Kvaček, V. Wilde, and C.-S. Li. 2013. Seeds of Weigela (Caprifoliaceae) from the early Miocene of Weichang, China and the biogeographical history of the genus. Taxon 62: 1009-1018.

Liang, X.-Q., V. Wilde, D.K. Ferguson, Z. Kvaček, A.G. Ablaev, Y.-F. Wang, and C.-S, Li. 2010. Comptonia naumannii (Myricaceae) from the early Miocene of Weichang, China, and the palaeobiogeographical implication of the genus. Review of Palaeobotany and Palynology 163: 52-63.
Ludwig, R. 1860. Fossile Pflanzen aus der ältesten Abtheilung der RheinischWetterauer Tertiär-Formation (Schluss). Palaeontographica Abteilung B Paläophytologie 8: 37-154.

Mai, D.H., and H. Walther. 1985. Die obereozänen Floren des Weißelster-Beckens und seiner Randgebiete. Abhandlungen des Staatlichen Museums für Mineralogie und Geologie zu Dresden 33: 1-260.

Manchester, S.R., and W.J. Kress. 1993. Fossil bananas (Musaceae): Ensete oregonense sp. nov. from the Eocene of western North America and its phytogeographic significance. American Journal of Botany 80: 1264-1272.

Menzel, P. 1913. Beitrag zur Flora der Niederrheinischen Braunkohlenformation. Jahrbuch der Preußischen Geologischen Landesanstalt zu Berlin 34: 1-98.

Nikitin, V.P. 2007. Paleogene and Neogene strata in northeastern Asia: Paleocarpological background. Russian Geology and Geophysics 48: 675-682.

No. 2 Regional Geological Survey Team, Hebei Bureau of Geology and Mineral Resources, 1979. Qipanshan section (K-50-16), Regional geological survey (1: 200000) of the People's Republic of China (in Chinese).

Rodríquez-de la Rosa, R.A., and S.R.S. Cevallos-Ferriz. 1994. Upper cretaceous Zingiberalean fruits with in situ seeds from southeastern Coahuila, Mexico. International Journal of Plant Sciences 155: 786-805.

Sanmartín, l., H. Enghoff, and F. Ronquist. 2001. Patterns of animal dispersal, vicariance and diversification in the Holarctic. Biological Journal of the Linnean Society 73: 345-390.

Scotese, C.R. 1997. Paleogeographic atlas, paleomap progress report no. 90-0497. Arlington: Department of Geology, University of Texas.

Scotese, C.R. 2001. PointTracker v4C. Arlington: PALEOMAP project, software.

Smith, A.G., D.G. Smith, and M.B. Funnell. 2004. Atlas of Mesozoic and Cenozoic coastlines, 99. Cambridge: Cambridge University Press.

Smith, S.Y., J.C. Benedict, M.E. Collinson, J. Skornickova, V. Wilde, F. Marone, J.L. Fife, M. Stampanoni, and X. Xiao. 2012. Seed morphology and evolution in Zingiberales: Insights from SRXTM. Japanese Journal of Palynology 58 (Special Issue: IPC-XIII/IOPC-IX Abstracts): 218-219.

Smith, S.Y., Collinson, M., Benedict, J., Specht, C., Marone, F., 2014. Revisiting Spirematospermum (Zingiberales) and its evolutionary significance. Botany 2014 - New Frontiers in Botany, 2014, the Boise Centre, Boise. Abstract ID: 695. Online Abstract: http://www.2014.botanyconference.org/engine/search/ index.php?func=detail\&aid $=695$

Tiffney, B.H. 1985. The Eocene North Atlantic land bridge: Its importance in tertiary and modern phytogeography of the northern hemisphere. Journal of the Arnold Arboretum 66: 243-273.

Tsukagoshi, M., and Y. Matsuhashi. 2012. Spirematospermum from Japan and its phytogeography. Japanese Journal of Palynology 58 (Special Issue: IPC-XIII/ IOPC-IX Abstracts): 241

Yi, T.-M., S. Molchanoff, and C.-S. Li. 2008. A preliminary report about Spirematospermum sp. from North China. In Biostratigraphic fundamentals of creating of the stratigraphic schemes of the Phanerozoic of Ukraine: Proceeding of the Institute of Geological Sciences, National Academy of Sciences of Ukraine ed. P.F. Gožyk, 205-208

\section{Submit your manuscript to a SpringerOpen ${ }^{\circ}$ journal and benefit from:}

- Convenient online submission

- Rigorous peer review

- Open access: articles freely available online

- High visibility within the field

- Retaining the copyright to your article

Submit your next manuscript at $\boldsymbol{\nabla}$ springeropen.com 